Revista de Derecho

de la Pontificia Universidad Católica de Valparaíso

XXXV (Valparaíso, Chile, 2010, $2^{\circ}$ Semestre)

[pp. $67-75$ ]

\title{
The Sale with Repurchase Clause
}

["La venta con cláusula de retrocompra"]

\author{
ILIE URS \\ "Dimitrie Cantemir" Christian University, Bucharest*
}

\section{RESUMEN}

La venta con cláusula de recompra fue regulada por el Código Civil de 1864, en sus artículos 1371-1387, como una variedad de venta afectada por una condición resolutoria. La venta con cláusula de recompra se utiliza con frecuencia en la práctica con el fin de violar las disposiciones de orden público del artículo 1689 del Código Civil rumano, en materia de hipoteca. Teniendo en cuenta que la venta con cláusula de recompra en realidad es una forma de incumplimiento de las disposiciones del artículo 1689 del Código Civil ruman, que origena una gran cantidad de abusos por parte de los acreedores, el legislador rumano decidió prohibir este tipo de venta. También consideramos que, de legeferenda, la aplicación de una ley nueva de prohibición de la venta con cláusula de recompra es necesario y útil.

Palabras Clave: Venta con cláusula de recompra - Venta obligatoria en razón de una hipoteca.
Abstract

The sale with repurchase clause was regulated in 1864 by the Civil Code, within the meaning of articles 1371-1387, as a variety of sale affected by a cancellation condition. The sale with repurchase clause was frequently used in practice in order to breach the public provisions of article 1689 of the Romanian Civil Code, on mortgage matters. Taking into consideration that the sale with repurchase clause was actually a way to breach the provisions of article 1689 of the Romanian Civil Code, giving birth to a lot of abuses on the part of the creditors, the Romanian legislator decided to prohibit this type of sale. We also consider that, de lege ferenda, the implementation of a new prohibition law of the sale with repurchase clause is both necessary and useful.

KEYwORDS: Sale with repurchase clause - Compulsory sale by mortgage.

* Senior Lecturer, Ph. D. , "Dimitrie Cantemir" Christian University of Bucharest, Faculty of Law, Cluj-Napoca, Romania.E-Mail:dr_ursilie@yahoo.com 


\section{Concept.}

The sale with repurchase clause ${ }^{1}$ was regulated in 1864 by the Civil Code, within the meaning of articles 1371-1387, as a variety of sale affected by a cancellation condition ${ }^{2}$. In the sale contract, the contracting parties used to provide for a special clause according to which the seller had the right/ was entitled to get back the item sold, within a specified timeline, by giving the buyer back the price he had paid and the contract expenses. This special clause, known as "repurchase clause" or "repurchase agreement", is the correspondent of a cancellation condition ${ }^{3}$ and must be expressly provided for in the sale contract ${ }^{4}$.

When the seller decides to put into practice the repurchase clause, the sale becomes instantly void (cancelled) whereas the item sold gets back to his patrimony.

Exercising the repurchase clause is one and the same with fulfilling the cancellation condition, producing the retroactive annulment of the sale contract, as if it had never existed. Consequently, the repurchase is not a new sale, going backwards; it stands for the annulment of the initial sale. In other words, the sale with repurchase clause does not involve two successive selling processes, but only one which becomes void in the favor of the seller'.

\section{Exercising the repurchase right.}

The right to repurchase is an ability which the seller can exercise or not ${ }^{6}$.

${ }^{1}$ Etymologically, the word "repurchase" comes from the Latin word redimo, -ere, meaning to repurchase.

${ }^{2}$ The "cancellation condition" is a future, uncertain event, whose fulfillment produces the retroactive annulment of the legal contracting relationship. See: STĂTESCU, C. - BÂrsan, C., Civil Law Treaty. General theory of Obligations (Bucharest, Publishing House of the Academy of the Social Republic of Romania, 1981), p. 375.

${ }^{3}$ See: Malaurie, Ph. - Aynes, L. - Gautier, P.-Y., Droit civil. Les contrats speciaux (Wolters Kluwer Publishing House 2009), p. 52 (the authors claim that the sale with repurchase clause is based on a cancellation condition). See: Hamangiu, C. Rosetti-BÂlănescu, I. - Băicoianu, Al., Treaty on the Romanian Civil Law (Bucharest, All Publishing House, 1997), II, p. 571.

${ }^{4}$ The Romanian traditional legal literature indicates that "the ability to repurchase" of the seller is exclusively an express cancellation condition which can only be stipulated on the date of the sale. Should the repurchase clause be stipulated in a separate, future document, the sale would be just a common selling act, whereas the repurchase would stand for a re-sale, namely a new sale, separate from the initial sale. See: HAmangiu, C.- Georgean, N., The Civil Code with Explanations (Bucharest, Alcalay Publishing House, 1932), III, p. 716.

${ }^{5}$ See: Alexandresco, D., Principles of the Romanian Civil Law (Bucureşti, Book House of the Royal Court F. Gobl Publishing House, 1926), VII, p. 258.

${ }^{6}$ See: CHIrICă, D., Treaty on the Civil Law. Special Contracts, I: Sale and Exchange 
Should the seller exercise it, the sale is retroactively cancelled, since the date the contract was entered into. The seller becomes again the owner of the sold item, whereas the subsequent sales agreed upon by the buyer in the meantime are cancelled ("resoluto jure dantis resolvitur jus accipientis").

Should the seller fail to exercise the repurchase right on the date established by law or agreed upon by the contracting parties, the right of the buyer becomes retroactively effective whereas the buyer becomes the final owner of the item bought on the date the sale was concluded. Accordingly, the conveyances agreed upon in the meantime by the buyer also become effective.

Concerning the way to exercise the ability to repurchase, most of the authors share the same opinion: should the seller want to put it into practice, he must make an offer of payment to the buyer ${ }^{7}$ by which he returns the repurchase price and the contract expenses. It is commonly decided that this is the only way by which the seller has seriously expressed his intent to get back the item he sold. The mere verbal expression of his willingness to do so is not enough to exercise the repurchase right $^{8}$.

In earlier times, the seller could exercise his right to repurchase not only against the buyer, but also against the subsequent buyers of the sold item, even though the repurchase agreement had not been stipulated in their contract (article 1370 the Romanian Civil Code). This was possible because, considering that he had a right subject to the cancellation condition, the buyer was unable to convey more property rights than he actually owned ("nemo dat quod non habet").

Apart from the seller, his heirs or creditors could also exercise the right to repurchase.

(Bucharest, C. H. Beck Publishing House, 2008), p. 296.

7 "An offer of payment" is a procedure which the debtor legally uses if the creditor refuses to receive the money he is entitled to. Firstly, the debtor sends the creditor a reminder (notification) by means of a bailiff, asking him to receive the money. The notification should include the place, time and hour when the payment is gong to be made. Should the creditor receive the money, the bailiff draws up the minutes stating that the debtor is free of obligations. On the other hand, should the creditor fail to receive the money or be present, the bailiff draws up the minutes stating the way things turned out, whereas the debtor deposits the money owned at C. E. C. Bank. The offer of payment, followed by the money transfer at C. E. C. Bank, releases the debtor from his responsibilities as if he had paid the money directly to de creditor.

${ }^{8}$ See: Hamangiu, C. - Rosetti-Bălănescu, I. - Băicoianu, Al., cit. (n. 3), pp. 573-574.

'See: Alexandresco, D., Theoretical and Practical Explanation of the Romanian Civil Law (Iaşi, National Book House, 1905), VIII, p. 778. 


\section{The deadline established for exercising the repurchase right.}

According to article 1373 of the Romanian Civil Code (now repealed), the seller could exercise the right to repurchase within 5 years since the sale. The contracting parties could also establish a shorter period of time; in this case, the seller could only exercise his right to repurchase within the specified time. In case the contracting parties would provide for a longer period of time than 5 years, the clause was not cancelled, but the term was reduced to the legal maximum period of time of 5 years. In case the contracting parties would establish no term, it was commonly assumed that the repurchase right could be exercised within 5 years since the sale, that is the parties adopted the legal term ${ }^{10}$.

The deadline established to exercise the repurchase right is predefined, not being subject to termination or suspension ${ }^{11}$.

\section{The origin of the institution.}

The sale with repurchase clause is rooted in the Roman Law where the repurchase agreement used to be known as pactum de retroemendo et de retrovendento ${ }^{12}$. It was regulated in older legislations in Romania, respectively in Calimach Code (article 1439 et seq.).

\section{The utility of the institution.}

At the time, when the Calimach Code was implemented and even after the Romanian Civil Code entered into force in 1864, the sale with repurchase clause was thought to be useful in practice. Before the organization of the modern mortgage system ${ }^{13}$, it was seen as a credit instrument. Thus, some people urgently needed money (cash), that's why they used to sell their assets, providing for the repurchase clause, hoping that they would be able to gather the necessary money to regain the property right of the sold items within the 5-year legal term or 'within the term agreed upon by the contracting parties.

On the other hand, the buyer hoped that the seller would not be financially able to repurchase the item(s) which, under such circumstances, was/ were to become his own for good.

${ }^{10}$ See: Hamngiu, C. - Rosetti-Bălănescu, I. - Băicoianu, Al., cit.(n. 3) , p. 572.

${ }^{11}$ See: Planiol, M. - Ripert, G. - Hamel, J. Traite pratique de droit civil francais (Paris, LGDJ., 1956), X, p. 227, no. 189.

${ }^{12}$ See: Nicolae, A. - Crăciun, N., Opinions on the Present Validity of the Sale Contract with Repurchase Clause, in "Dreptul" Magazine, 3 (2001), pp. 17-26.

${ }^{13}$ Ibid., p. 18. 


\section{goal. \\ 6. Re-routing the sale with repurchase clause from its legally regulated}

The sale with repurchase clause was frequently used in practice in order to breach the public provisions of article 1689 of the Romanian Civil Code, on mortgage matters.

According to article 1689 , should the debtor fail to fulfill his obligation when the time is due, the creditor may not keep the item that the debtor offered him as mortgage, nor may he use it; in this case, the sale by means of a bailiff is compulsory; any contract provision stipulating that the creditor should become the owner or user of the mortgage item, disregarding the formalities under the law (pignorative contract), becomes ineffective. Consequently, in order to recover the debts, the creditor shall go through the forced execution procedure, as provided by the law.

The interdiction within article 1689 of the Romanian Civil Code has been eluded via the sale with repurchase clause as follows: the contracting parties used to perform a simulated operation in which the creditor played the role of the "buyer" and the debtor played the role of the "seller" stipulating the repurchase clause (agreement).

For instance, a creditor gave his debtor a loan at a high rate of interest $\mathrm{t}^{14}$ (this loan contract was the real, authentic legal agreement concluded by the parties), asking as a guarantee for getting back his money an asset whose value significantly exceeded that of the loan; as he was in urgent need of money, the debtor had no other choice but to bring the asset and sign a sale contract with repurchase clause (this was the apparent, simulated contract). The price specified in the apparent sale contract with repurchase clause was much higher than the loan itself (in reality, the price stood for the amount of money received by the debtor in the form of the loan plus the interest incurred). Considering that, within the period of time established by law or agreed upon by the parties, the debtor ("seller") did not exercise his right to repurchase the item in exchange of the price agreed upon, the creditor ("buyer") became the final owner of the item without having to follow the forced execution procedure, thus gaining a great advantage. At that time, in most of the cases, the price specified in the sale contract was so high that the "seller" was hardly in capacity to exercise the right to repurchase.

In some other instances, the contracting parties ("the seller" and "the buyer") would sign a sale contract with repurchase clause, secretly aiming

${ }^{14}$ The "interest established by the money lender" is an illegal conventional interest required by the creditor, whose value significantly exceeds the legally established maximum interest. 
to guarantee the repayment of an interest-based loan taken from a money lender and given by the "buyer" to a third party ${ }^{15}$.

Taking into consideration that the sale with repurchase clause was actually a way to breach the provisions of article 1689 of the Romanian Civil Code, giving birth to a lot of abuses on the part of the creditors, the Romanian legislator decided to prohibit this type of sale. Consequently, within the meaning of article 4 of Act 61/1931 against the interest paid to a money lender ${ }^{16}$, the sale contracts with repurchase clause were taken out of force, whereas the provisions of articles 1371-1387 of the Civil Code were repealed ${ }^{17}$.

Such annulment meant to prevent the money lenders' practices under which creditors used to take away ("buy") from their debtors items of a value much higher than that of the respective loan and subsequently keep them as their own when payment was due, in case the debtors failed to fulfill their obligation.

7. The abrogation of the legal provisions which probibited the sale with repurchase clause and its consequences at present.

The Act against the interest paid to a money lender of 2 April 1931 was repealed by the Decree 1700 of 5 May $1938^{18}$ on the establishment of legal interest and the elimination of interest paid to money lenders; however, the provisions of article 4 of the repealed Act, prohibiting the sale with repurchase clause, were introduced in article 13 of the new Act.

Decree 1700 of 5 May 1938 was repealed by Decree 311/1954 which no longer included an express provision prohibiting the sale with repurchase clause. Nevertheless, for a long period of time (1954-2000), the case-law failed to take into consideration this aspect and unrighteously considered as void the sale with repurchase clause ${ }^{19}$.

${ }^{15}$ For certain legal aspects, see: Niculescu, M., Opinions on how to Guarantee Loans Based on Interest Paid to Money Lenders, in Studia Universitatis Babeş-Bolyai Magazine, 1 (2000), p. 88-89 et seq.

${ }^{16}$ Act 61/1931 against the interest paid to money lenders was published in the OJ of Romania, part I, no. 77 of 2 April 1931. According to article 4 of this Act: "The sale contracts with repurchase and anticrisis clause concluded between parties after the enforcement of this Act, shall be void, whereas the provisions of Articles 1371-1387 of the Civil Code and of Articles 1697-1703 of the Civil Code shall be repealed".

${ }^{17}$ See: Mureşan, M., Civil Code. Special Contracts. Academic Course (Cluj-Napoca, Cordial Lex Publishing House, 1999), p. 55.

${ }^{18}$ Published in the OJ of Romania, part I, no. 102 of 5 May 1938.

${ }^{19}$ Chirică, D., Civil Code. Special Contracts (Bucharest, Lumina Lex Publishing House, 1997), pp. 58-59; Mureşan, M., cit. (n. 17), p. 54-56; Deak, F., Treaty on Civil Code. Special Contracts (Bucharest, Universul Juridic Publishing House, 2001), 
Starting with 2000, Court Houses ${ }^{20}$ and the Romanian legal literature ${ }^{21}$ righteously agreed that the sale with repurchase clause is now a valid convention, as it is no longer expressly prohibited by law.

The sale contract with repurchase clause shall be governed by the general rules applicable to all conventions and it can only be declared void under the common law (for example, out of illicit or immoral causes) ${ }^{22}$.

\section{Conclusions and "de lege ferenda" proposals (in English "what the law should be").}

Following the abrogation of the legal provisions prohibiting the sale with repurchase clause, it is essential to know what the status of this type of sale is at present.

It is commonly agreed that the abrogation of the legal provisions prohibiting the sale with repurchase clause does not necessarily lead to the reenforcement of articles 1371-1387 of the Romanian Civil Code, which were previously repealed ${ }^{23}$. Considering that it is no longer expressly prohibited by law, we believe that the parties can at any time enter into a sale convention with repurchase clause. As it appears in the Romanian legal literature, the validity of such a convention shall be analyzed depending on the general conditions of validity of the legal instrument ${ }^{24}$.

Another issue to be considered refers to how long the right to repurchase can be exercised. At present, the sale with repurchase clause is no longer

p. 104. As far as the legal practice is concerned, see the Supreme Court, Civil Decision no. 964/1955, in the Collection of Decisions Cluj-Napoca Court House, 1955, p. 6163, civil sentence no. 1020/1999, not-published; Cluj-Napoca Court House, civil sentence no. 8278/1999, not-published; (Cluj-Napoca Court House), civil sentence no. 9526/1999, not-published (in all these instances, the Court decided that the parties had concluded a sale contract with repurchase clause, with the intention to guarantee a loan based on interest paid to money lenders). Consequently, within the meaning of Article of Act 61/1931 against the interest paid to money lenders, they decided the absolute cancellation of those sale contracts.

${ }^{20}$ See: Court of Appeal, Bucharest, section VI civil, Decision no. 3136/R/2000, published in "Dreptul" Magazine, 12 (2000), p. 132-133; Court of Appeal, Cluj, civil, Decision no. 2508/2002, in Bulletin 2002 (Bucharest, Lumina Lex Publishing House, 2003), p. 103 et seq.

${ }^{21}$ In the legal literature, see: NiCOlaE A. - CRĂCIUN, N., cit. (n. 12), p. 17-26; Rădulescu, O. - Rădulescu, P. - Rădulescu, A., The Sale with Repurchase Agreement, in Magazine for Commercial Law, 1 (2001), p. 44 et seq; Munteanu, I. R., The Sale with Repurchase Agreement, in Pandectele Române, 1 (2004), p. 242 et seq; CHIrICĂ, D., Treaty, cit. (n. 6), p. 294.

${ }^{22}$ See: Nicolae, A. - Crắciun, N., cit. (n. 12), p. 22

${ }^{23}$ See: Chirică, D., Treaty, cit. (n. 6), p. 294

${ }^{24}$ See: Nicolae, A. - CrĂCiUn, N., cit. (n. 12), p. 25. 
regulated under any law, whereas the former article 1373 of the Romanian Civil Code, according to which the maximum term was 5 years, was repealed. Under these circumstances, we consider that the right to repurchase cannot be exercised indefinitely, as it would prejudice the principle of civil circuit security and the stability of legal relationships. Even in the absence of a written text, we consider that the parties can provide for a reasonable term in their convention; should they fail to provide for a specific term, the right to repurchase must be exercised within 3 years since the conclusion of the contract.

We also consider that, de lege ferenda, the implementation of a new prohibition law of the sale with repurchase clause is both necessary and useful. To support our opinion, it is obvious that the sale with repurchase clause is used to disguise loans at high rates of interest paid to money lenders and to breach the compulsory provisions of article 1689 of the Civil Code. The recent case-law proves that the sale with repurchase clause is frequently used to mask a loan at a high rate of interest paid to money lenders ${ }^{25}$, and the present social-economic environment in Romania favors such a practice, under various forms. Consequently, we strongly support the implementation of a new prohibition norm of the sale with repurchase clause or at least of a norm strictly and accurately regulating this type of sale.

[Recibido el 10 y aprobado el 23 de septiembre de 2010].

\section{BIBLIOGRAFÍA}

Alexandresco, D., Principles of the Romanian Civil Law (Bucureşti, Book House of the Royal Court F. Gobl Publishing House, 1926), VII.

Alexandresco, D., Theoretical and Practical Explanation of the Romanian Civil Law (Iaşi, National Book House, 1905), VIII.

ChIrICă, D., Civil Code. Special Contracts (Bucharest, Lumina Lex Publishing House, 1997).

CHIRICĂ, D., Treaty on the CivilLaw. Special Contracts, I: Sale and Exchange (Bucharest, C. H. Beck Publishing House, 2008).

Deak, F., Treaty on Civil Code. Special Contracts (Bucharest, Universul Juridic Publishing House, 2001).

Hamangiu, C. - Rosetti-BÂlănescu, I. - Băicoianu, Al., Treaty on the Romanian Civil Law (Bucharest, All Publishing House, 1997), II.

Hamangiu, C. - Georgean, N., The Civil Code with Explanations (Bucharest, Alcalay Publishing House, 1932), III.

\footnotetext{
${ }^{25}$ See: Cluj-Napoca Court House, civil sentence no. 1020/1999, not-published; civil sentence no. 9526/1999, not-published; civil sentence 8278/1999, not-published.
} 
Malaurie, Ph. - Aynes, L. - Gautier, P.-Y., Droit civil. Les contrats speciaux (Wolters Kluwer Publishing House 2009).

Munteanu, I. R., The Sale with Repurchase Agreement, in Pandectele Române, 1 (2004).

Mureşan, M., Civil Code. Special Contracts. Academic Course (Cluj-Napoca, Cordial Lex Publishing House, 1999).

Nicolae, A. - Crăciun, N., Opinions on the Present Validity of the Sale Contract with Repurchase Clause, in "Dreptul" Magazine, 3 (2001).

Niculescu, M., Opinions on how to Guarantee Loans Based on Interest Paid to Money Lenders, in Studia Universitatis Babeş-Bolyai Magazine, 1 (2000).

Planiol, M. - Ripert, G. - Hamel, J. Traite pratique de droit civil francais (Paris, LGDJ., 1956), X.

Rădulescu, O. - Rădulescu, P. - Rădulescu, A., The Sale with Repurchase Agreement, in Magazine for Commercial Law, 1 (2001).

StĂTEsCu, C. - BÂRsAn, C., Civil Law Treaty. General theory of Obligations (Bucharest, Publishing House of the Academy of the Social Republic of Romania, 1981). 